\title{
Serum Vascular Endothelial Growth Factor and Insulin- Like Growth Factor-1 in Liver Cirrhosis: Relation to Disease Severity and Development of Portal Hypertension
}

\author{
Soha Saoud Abdel-moneim *, Ehab F. Abdou *, \\ Amany Osama**, Nagwa S. Ahmed*** \\ Department of Tropical Medicine and Gastroenterology, Faculty of \\ Medicine, Assiut University *, \\ Biochemistry Department, Faculty of Medicine, Assiut University**, \\ Biochemistry Department, Faculty of Medicine, Sohag university***
}

\begin{abstract}
Aims: To assess the level of Vascular Endothelial Growth factor (VEGF) and Insulinlike Growth Factor -1(IGF-1) in serum of patients with liver cirrhosis and correlate them to Child-Pugh classes and to correlate Vascular Endothelial Growth factor to Color Doppler indices of portal and splenic veins. Patients and Methods: fifty-five patients with liver cirrhosis and ten healthy controls were chosen. They underwent a thorough history, physical examination, abdominal ultrasonography and Color Doppler examination of portal vein and portal pressure. The serum levels of VEGF and IGF-1 were measured using commercial ELISA kits. Results: The median (and interquartile range) of serum VEGF was significantly lower in patients than controls (120ng/L [110-330] and 341ng/L [258-990] respectively, $p$ value $<0.001)$, also there was a significant decrease in IGF-1 in patients than controls $(34 \mathrm{ng} / \mathrm{ml}$ [23-48.3] and $147.2 \mathrm{ng} / \mathrm{ml}[125.8-220.2]$ respectively, $p$ value $<0.000)$. There was a significant difference in median serum VEGF and IGF-1 levels among the different Child-Pugh classes (class A: 110ng/L [109-120], class B: 120.5ng/L [120-462], and class C $126.5 \mathrm{ng} / \mathrm{L}$ [110-286], $p$ value < 0.005 for VEGF and class A: 48.3ng/ml [42.8-49.4], class B: $23 \mathrm{ng} / \mathrm{ml}$ [20.8-34], and class C 36.6ng/ml [32.3-49.7], $p$ value $<0.000$ for IGF-1). A significant positive correlation was noted between serum VEGF and maximum portal vein velocity and maximum splenic vein velocity (Spearman's $r=$ $0.780, r=0.693$ respectively, $p$ value $<0.000$ ). A significant negative correlation was noted between serum VEGF and the hepatic artery resistance index and splenic hilar diameter (Spearman's $r=-0.462, r=-0.695$ respectively, $p$ value $<0.000$ ). Significant positive correlation was found between IGF-1 serum levels and serum albumin (Spearman's $r=0.310, p$ value $=0.012$ ). No correlation was found between VEGF serum levels and serum albumin. Conclusion: Circulating VEGF level in patients with liver cirrhosis could not serve as an indicator of the progression of liver cirrhosis but rather it may reflect development of complication in the form of portal hypertension. Also, liver cirrhosis is associated with changes in serum IGF-1 that is related to the degree of liver dysfunction.

Key words: vascular endothelial growth factor, insulin like growth factor-1, liver cirrhosis, portal hypertension.
\end{abstract}




\section{INTRODUCTION}

Liver cirrhosis constitutes a major health problem in Egypt. Portal hypertension is a complication of liver cirrhosis. Portal hypertension is associated with the development of a porto-systemic collateral circulation which decompresses the portal vascular system.

Vascular endothelial growth factor (VEGF), $46 \mathrm{kDa}$ dimeric protein, is a direct and specific mitogen for endothelial cells. It induces migration, proliferation and survival of endothelial cells ${ }^{(1)}$. At the liver level, VEGF is significantly expressed by sinusoidal endothelial cells and hepatocytes ${ }^{(2)}$. VEGF has been extensively investigated recently in various hepatic diseases such as hepatitis, liver cirrhosis, primary and secondary hepatocellular carcinoma. VEGF serum concentration was found to increase in acute hepatitis and decrease in chronic hepatitis and liver cirrhosis $^{(3)}$, which suggests that VEGF levels might correlate with disease severity. Moreover, VEGF circulating level was found to be closely related to Child-Pugh classification in cirrhotic liver ${ }^{(4)}$

Portal hypertension is a complication of liver cirrhosis and is associated with the development of a porto-systemic collateral circulation. Until recently, it was thought that the development of collateral circulation was due to the passive opening of vascular channels in response to increased portal pressure. However, recent studies showed that the formation of collateral circulation may be, at least in part, due to angiogenesis driven by VEGF ${ }^{(5)}$.

Insulin-like growth factor I (IGFI) is a polypeptide hormone secreted by multiple tissues in response to growth hormone $(\mathrm{GH})$. It is partly responsible for $\mathrm{GH}$ activity, and also has glucose lowering and anabolizing effects $^{(6)}$.

Insulin-like growth factor-1 (IGF1) also called somatostatin, low molecular peptide, is considered an important anabolic hormone inducing anabolic metabolism and stimulating DNA synthesis, cell proliferation and meiotic division in a variety of tissues (7). The liver is the main source of circulating IGF-1 and its synthesis is regulated by the growth hormone. Serum level of IGF-1 was found to decrease in liver cirrhosis ${ }^{(8)}$.

The present study aims to assess the serum level of VEGF and IGF-1 in patients with liver cirrhosis and correlate them to Child-Pugh classes and to correlate VEGF to Color Doppler indices of portal vein and splenic vein.

\section{PATIENTS \& METHODS}

\section{Patients}

A total of 70 patients with liver cirrhosis were recruited from the Inpatient Department of Tropical Medicine and Gastroenterology, Assiut University Hospital. All patients were diagnosed by clinical, biochemical and radiological findings as liver cirrhosis. The severity of liver disease was evaluated by the Child Pugh's score. Portal hypertension was clinically implied by the presence of ascites, splenomegaly, encephalopathy and/or history of bleeding varices that occurs in the presence of known chronic liver disease. Using the ultrasound and Doppler ultrasound portal hypertension was, also, suggested by the presence of hepatic architectural changes suggesting 
chronic liver disease, splenomegaly (spleen hilar diameter $>4.5 \mathrm{~cm}$, longitudinal diameter $>11 \mathrm{~cm}$ ) ${ }^{(9,10)}$, portal vein diameter greater than 1.25 $\mathrm{cm}$, portal vein flow velocity $<21 \mathrm{~cm} / \mathrm{sec}$, and congestion index exceeded $0.1^{(11)}$.

In addition to ten healthy controls were included in the study. The control group underwent the same clinical, biochemical, and radiological examination as patients group.

Abdominal

ultrasonography/Doppler

examination:

\section{Equipment}

The ultrasound equipment used for Doppler studies was Siemens Sonoline Sienna Ultrasound Imaging System, (Siemens, Germany), software version 1.5, 2.0 and 3 with frequency range $(2.5-5 \mathrm{MHz})$.

\section{B-mode Examination}

Spleen hilar and longitudinal diameter, portal vein diameter in $\mathrm{mm}$, the portal vein cross-sectional area in $\mathrm{cm}^{2}$ and splenic vein diameter in $\mathrm{mm}$ were measured using B-mode.

\section{Doppler Examination}

All patients were studied after fasting overnight or for at least 6 hours and a resting period of 15 minutes in the supine position prior to the examination. The examination was carried by a single experienced examiner who was unaware of the grade of cirrhosis so as to prevent bias. The following parameters were recorded during the examination: 1) portal vein maximum velocity $\left(\mathrm{V}_{\max }\right)$ in $\mathrm{cm} / \mathrm{sec}, 2$ ) hepatic artery resistance index (RI), and 3) Splenic vein maximum velocity $\left(\mathrm{V}_{\max }\right)$ in $\mathrm{cm} / \mathrm{sec}$.

Blood samples were collected from overnight fasted patients and controls. Specimens were allowed to clot, the sera were separated and stored frozen at $-70^{\circ} \mathrm{C}$ until assayed.

Determination of serum level of VEGF:

Concentration of serum VEGF was measured using ELISA kit that contains all components required for the quantitative measurements which was provided by Koma Biotech Inc.

Determination of serum level of IGF-1:

The concentration of IGF-1 in serum samples was done using ELISA technique that uses antibodies with high affinity and specificity for two different epitopes on IGF-1. The ELISA kit was provided by Biosource, Europe.

Determination serum level of alanine transferase (ALT), aspartate transferase (AST) and albumin by using colorimetric method provided by Stanbio Laboratory and serum level of bilirubin by Quimica Clinical Aplicada.

\section{Statistical analysis:}

Data was entered and analyzed using SPSS version 13 for Windows. Nonparametric statistics were used throughout the analysis. Quantitative variables were summarized as median (interquartile range). Nominal and ordinal variables were summarized as ratios. The significance of the difference between two groups was assessed using Mann-Whitney's U statistic and Kruskall-Wallis test was used to test the difference between more than two groups. Bivariate correlations were analyzed using Spearman's rank correlation coefficient.

\section{RESULTS}

Out of 70 patients who were eligible, we were unable to obtain 
reliable Doppler indices in 8 patients. Seven patients were, also, excluded from the study after ultrasonographic examination (4 had hepatic focal lesions and 3 had portal vein thrombosis). That left 55 patients in the patient's group for analysis.

Baseline characteristics of the study population are presented in table (1). Thirteen patients were Child Pugh's class A, 22 were Child class B, and 20 were Child class $C$.

The median of VEGF in patients with liver cirrhosis was significantly less than controls (120ng/L (110-330) versus $\quad 341 \mathrm{ng} / \mathrm{L} \quad(258-990))$ respectively, $\mathrm{P}$ value $<0.001)$. Insulinlike growth factor was, also, significantly less in patients than controls (34 $\mathrm{ng} / \mathrm{ml} \mathrm{(23-48.3)} \mathrm{versus}$ $147.2 \mathrm{ng} / \mathrm{ml}$ respectively, $\mathrm{P}$ value $<0.000$ ).

The serum levels of VEGF and IGF-1 in different Child-Pugh classes are presented in table (2). There was a significant difference in median serum VEGF levels among the different Child-Pugh classes ( $p$ value $<0.005$ ). Vascular endothelial growth factor was positively correlated to Child-
Pugh classes (Spearman's $\mathrm{r}=0.120, \mathrm{p}$ value $=0.381$ ), and IGF-1 was negatively correlated to Child-Pugh classes (Spearman's $\mathrm{r}=-0.030, \mathrm{p}$ value $=0.826$ ).

A statistically significant positive correlation was found between VEGF and maximum portal vein velocity (figure 1) and maximum splenic vein velocity (Spearman's $\mathrm{r}=0.780, \mathrm{r}=$ 0.693 respectively, $\mathrm{p}$ value $<0.000$ ). A significant negative correlation was found between VEGF and hepatic arterial resistance index and spleen hilar diameter (Spearman's $r=-0.462$, $\mathrm{r}=-0.695$ respectively, $\mathrm{p}$ value $<$ $0.000)$. No significant correlation was noted between VEGF and both portal vein diameter and splenic vein diameter (Spearman's $\mathrm{r}=0.049, \mathrm{p}$ value .696 and $r=-0.132, p$ value 0.295 respectively). A significant positive correlation was found between IGF-1 and albumin (Spearman's $r=0.310, p$ value 0.012 ) However, no correlation was found between VEGF and serum albumin (Spearman's $\mathrm{r}=0.082, \mathrm{p}$ value $=$ $0.554)$.

Table (1): Baseline clinical, biochemical and radiological characteristics in patients and controls (median (interquartile range)

\begin{tabular}{|l|c|c|}
\hline \multicolumn{1}{|c|}{ Characteristic } & Patients $(\mathbf{n}=\mathbf{5 5})$ & Control $(\mathbf{n}=\mathbf{1 0})$ \\
\hline Age (years) & $51(25-57)$ & $43.5(30.3-54)$ \\
\hline Sex (M/F) & $31 / 24$ & $6 / 4$ \\
\hline Albumin (g/l) & $22(19-26.6)$ & $43(40.8-44.5)$ \\
\hline Bilirubin ( $\boldsymbol{\mu m o l} / \mathbf{l})$ & $37(22-53)$ & $4.8(3.7-5.9)$ \\
\hline AST( IU/L) & $68(47-85)$ & $20(14.5-27.8)$ \\
\hline ALT (IU/L) & $48(33-69)$ & $18.5(14.8-25.8)$ \\
\hline Portal vein diameter (mm) & $13.1(12-14.5)$ & $9.9(9.2-10.1)$ \\
\hline Portal vein velocity (cm/sec) & $18(16-21)$ & $26.5(42.5-30)$ \\
\hline Splenic hilar diameter (cm) & $5.5(4.9-6.6)$ & $3.9(3.5-4)$ \\
\hline Splenic vein diameter $(\mathbf{m m})$ & $10(8.9-11.9)$ & $8.1(7.9-8.5)$ \\
\hline Splenic vein velocity $(\mathbf{c m} / \mathbf{s e c})$ & $21.4(18-27)$ & $29(27-30.3)$ \\
\hline
\end{tabular}


Table (2): The median (interquartile range) serum levels of VEGF and IGF-1 in different Child-Pugh classes

\begin{tabular}{|l|c|c|}
\hline \multicolumn{1}{|c|}{ Child Classes } & VEGF (ng /L) & IGF (ng/ ml) \\
\hline Child A (n=13) & $110(109-120)$ & $48.3(42.8-49.4)$ \\
\hline Child B (n=22) & $120(120-462)$ & $23(20.8-34)$ \\
\hline Child C (n=20) & $126(110-286)$ & $36.6(32.3-49.7)$ \\
\hline p-value & 0.005 & 0.000 \\
\hline
\end{tabular}

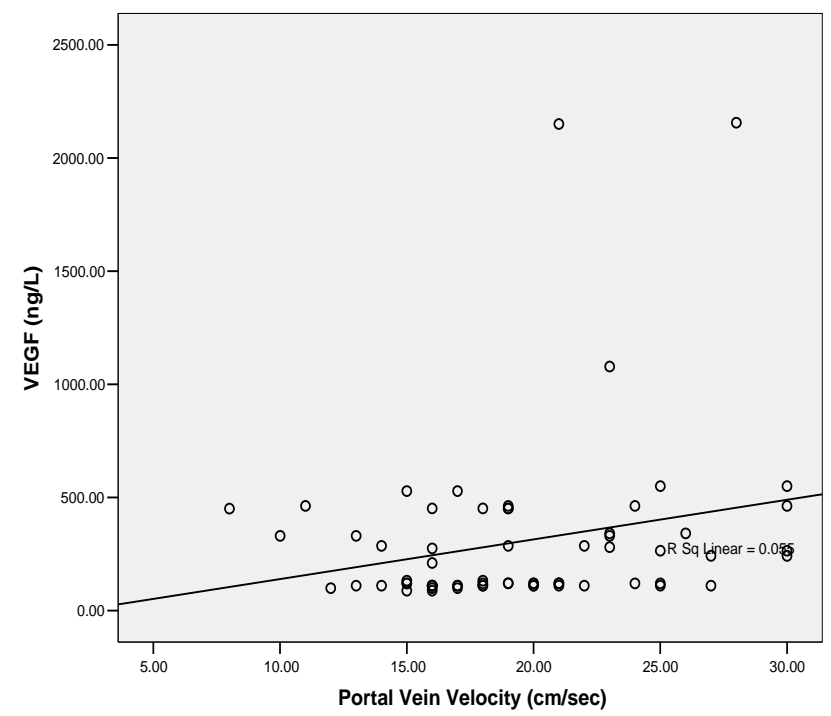

Figure (1): Correlation between VEGF levels and portal vein blood velocity in patients with liver cirrhosis $(r=0.780)(p$ value $<0.000)$.

\section{DISCUSSION}

The present study clearly demonstrates the reduction of VEGF in patients with cirrhosis than the control group and a positive correlation to Child- Pugh classes. There is, also, a significant relation between VEGF serum levels and three accurate radiological parameters of portal hypertension, portal vein velocity, hepatic artery resistance index and splenic hilar diameter.

The findings of VEGF changes with cirrhosis agree with others ${ }^{(4,12,13)}$. This could be attributed to increased activity of several inhibitor substances including angiostatin and endostatin in liver cirrhosis ${ }^{(\mathbf{1 3})}$. The low circulating VEGF levels in patients with liver cirrhosis, also, indicate that VEGF was derived neither from a large burden of tumor cells as hepatocellular 
carcinoma was excluded from the study nor from platelet activation by portal vein thrombosis which was, also, excluded.

The increase in the median serum levels of VEGF with Child-Pugh stage was, also, reported by Assy et al. ${ }^{(12)}$ Such increase could be attributed to the positive regulators such as the acute phase proteins, tumor necrosis factor- $\alpha$ (TNF- $\alpha)$ and transforming growth factor- $\beta$ (TGF- $\beta$ ), and the proinflammatory cytokines such as interleukin-1(IL-1) and interleukin-6 (IL-6) which are unregulated in liver cirrhosis ${ }^{(14)}$. However, Fuyuhiko et al., (3) reported a decrease in VEGF serum levels with the progression in Child-Pugh classes which may suggest that serum VEGF may be associated with hepatocyte regeneration grade. VEGF has been shown to induce the proliferation of hepatic sinusoidal cells by virtue of increased expression of its receptors flt-1 and flk-1 following partial hepatectomy. ${ }^{(2,15)}$

Furthermore, Assy et al. ${ }^{(12)}$ noted that exogenous VEGF isoform 165 administration to partially hepatectomized rats stimulate liver cell proliferation. It is likely that hepatocyte proliferation requires growth factors such as hepatocyte growth factor (HGF) and transforming growth factor- $\alpha$ (TGF- $\alpha$ ) in the early phase that directly stimulate hepatocytes randomly at the periportal areas but is rarely accompanied by reconstruction of the architecture of hepatic sinusoids, and growth factors that indirectly stimulate hepatocytes, such as VEGF, in the late phase where proliferative hepatocytes express VEGF to obtain sufficient blood flow by accompanying reconstruction of the architecture of hepatic sinusoids.

The relation to portal hypertension was, also, reported by others $^{(\mathbf{1 2 , 1 6})}$. This confirms the contention that VEGF plays a role in the neovascularization process through angiogenesis and vasculogenesis in liver cirrhosis. Fernandez et al. ${ }^{(5)}$ demonstrated that the development of hyperdynamic circulation and formation of porto-systemic collateral vessels in portal hypertensive rats are angiogenesis-dependent process that could be markedly inhibited by blockage of VEGF signaling pathway.

Insulin like growth factor-1 (IGF1) is a peptide hormone with metabolic and trophic actions particularly on skeletal muscle and bone ${ }^{(\mathbf{1 7 )}}$. The adult liver is considered to represent the major source of circulating IGF-1 ${ }^{(\mathbf{1 8 , 1 9})}$ and decreased serum IGF-1 concentrations have been reported in patients with liver disease $^{\mathbf{( 2 0 )}}$, this agree with the present results that demonstrates a reduction of IGF-1 in patients with cirrhosis than the control group and a negative correlation to Child- Pugh classes. The decreased serum IGF-1 concentration in patients with liver cirrhosis is considered to be the result of reduced hepatic synthesis.

Scharf et al. ${ }^{(21)}$ reported that serum IGF-1 concentrations were correlated with serum albumin. This finding further indicates that the reduction in hepatocellular function provides an explanation for low IGF-1 concentrations in patients with cirrhosis.

In conclusion, circulating VEGF level in patients with liver cirrhosis could not serve as an indicator of the 
progression of liver cirrhosis but rather, it may reflect development of complication in the form of portal hypertension. Also, liver cirrhosis is associated with decrease in serum IGF-1 that is related to the degree of liver dysfunction.

\section{REFERENCES}

1. Leung DW, Cachianes G, Kuang WJ , Goeddel WJ and Ferrara N.(1989): Vascular endothelial growth factor is a secreted angiogenic mitogen. Science 246: 1306-1309.

2. Yamane A, Seetharam L, Yamaguchi S, Gotoh $\mathbf{N}$, Takahashi T, Neufeld GA and Shibuya M .(1994): A new communication system between hepatocytes and sinusoidal endothelial cells in liver through vascular endothelial growth factor and Flt tyrosine kinase receptor family (Flt-1 and KDR/FLK-1). Oncogene 9:2683-2690.

3. Fuyuhiko A, Michio S, Hiroshi S, Yasuyo U, Keiichi M, Katsuhiko $M$ and Kyuichi T. (1998): Serum vascular endothelial growth factor levels in various liver diseases. Digestive Diseases and Sciences 43: 41-45.

4. Desideri $G$ and Ferri C. (2000): Circulating vascular endothelial growth factor levels are decreased in patients with chronic hepatitis and liver cirrhosis depending on the degree of hepatic damage. Clinical Science 99:159-160.

5. Fernandez $M$, Mejias $M$, Angermayr B, Garcia -Pagan J.C, Rodes $J$ and Bosch J. (2005): Inhibition of VEGF receptor-2 decreases the development of hyperdynamic splanchnic circulation and portal systemic collateral vessels in portal hypertensive rats. J. Hepatol., 43: 98-103.

6. Conchillo M, Prieto J, Quiroga J (2007): Insulin-like growth factor-1(IGF-I) and liver cirrhosis. Rev. Esp. Enfen . Dig., 99(3):156-164.

7. Garcia-Fernandez M, CastillaCortazar I, Diaz-Sanchez M, Diez Caballero F, Castilla A, Diaz Casares A, Varela-Nieto I, Gonzalez-Baron S.(2003): Effect of IGF-1 on total serum antioxidant status in cirrhotic rats. J. Physiol Biochem., 59: 145-146.

8. Wu Yun-Lin, Ye Jing, Zhang Shu, Zhong Jie , Xi Rong -Ping ( 2004): Clinical significance of serum IGF-I and IGF-II and IGFBP-3 in liver cirrhosis. World J. Gastroenterol., 10(18): 27402743.

9. Jarvis L, Cook PG, James CM, Bolognesi M, Merkel C. (1991): Duplex sonography in splenomegaly. Br. J. Radiol., 64 (762): 485-8.

10. Haag K, Weimann A, Zeller O, Klein CP, Kalk JF.( 1992): Splenic size and duplex sonography determination of blood flow in the vena lienalis and vena portae in liver cirrhosis. Bildgebung., 59 (2):80-3.

11. Haag $K$, Rossle $M$, Ochs $A$, Huber M , Siegerstetter V , Olschewski M, Berger E, Lu S and Blum $H$ (1999): Correlation of duplex sonography findings and portal pressure in 375 patients 
with portal hypertension. Am. J. Roentgenol., 172:631-5.

12. Assy N, Paizi M, Gaitini D, Baruch Y, Spira G. (1999): Clinical implication of VEGF serum levels in cirrhotic patients with or without portal hypertension. World J. of Gastroenterology 5(4): 296-300.

13. Raymond E.( 1998) : Tumor angiogenesis inhibitors: media and scientific aspects. Presse. Med., 43: 1221-1224.

14. Moshage H. (1997): Cytokines and hepatic acute phase response. J .Pathol., 181: 257-266.

15. Eitaro Taniguchi, Shotaro Sakisaka, Katsuhiko Matsuo, Paizi M, Shankar L, Kraizer Y.( 2001): Expression and role of vascular endothelial growth factor in liver regeneration after partial hepatectomy in rats. J. Histochemistry \& Cytochemistry 49(1): 121-129.

16. Iwao $\mathrm{T}$, Toyonaga A, Oho $\mathrm{K}$, Oho K, Tayama C, Masumato H, Sakao T, Sato M, Tanikawa K .( 1997): Value of Doppler ultrasound parameters of portal vein and hepatic artery in the diagnosis of cirrhosis and portal hypertension. Am. J. Gastroenterol., 92: 1012-1017.
17. Florini JR, Ewton DZ.(1992) Inductionn of gene expression in muscle by the IGF-1. Growth Regul., 2:23-9.

18. Schwander JC, Hauri C, Zapf J, Froesch ER.( 1983): Synthesis and secretion of insulin-like growth factor and its binding protein by perfused rat liver: dependence on growth hormone status. Endocrinology., 113:297305.

19. Mathews LS, Norstedt G, Palmiter RD. (1986): Regulation of insulin-like growth factor gene expression by growth hormone. Proc. Natl. Acad .Sci. (USA); 83:9343-47.

20. Shmueli E, Stewart M, Alberti KG Record C .(1993): Growth hormone, Insulin like growth factor-1 and insulin resistance in cirrhosis. Hepatology 19:322-8.

21. Scharf, J, Schmitz F, Frystyk J, Skjaerbaek C, Moesus H, Blum WM Ramadori G, Hartmann H.( 1996): Insulin-like growth factor-1 serum concentrations and patterns of insulin-like growth factor binding proteins in patients with chronic liver disease. J. of Hepatol., 25:689-699. 


\title{
عامل النمو للطبقة الطلائية المبطنة للاوعية الاموية وعامل النمو الثبيه للانسولين - ا فى مرضى تليف الكبد: وعلاقته بحدة المرض وحدوث ارتفاع الضغط الباب؟ى
}

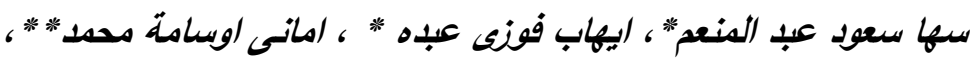

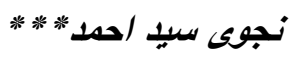

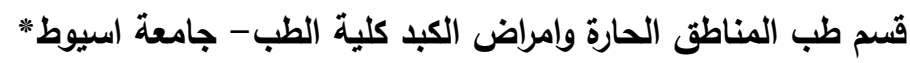

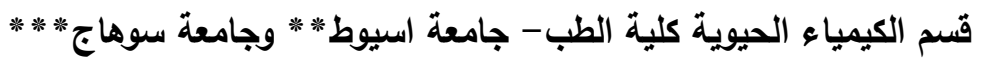

يهذف هذا البحث الى قياس مسنوى عامل النمو للطبقة الطلائية المبطنة للاوعية الاموية

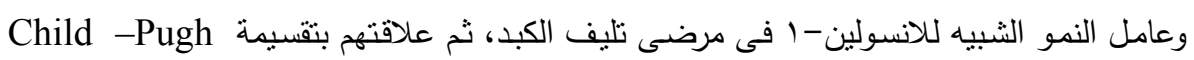

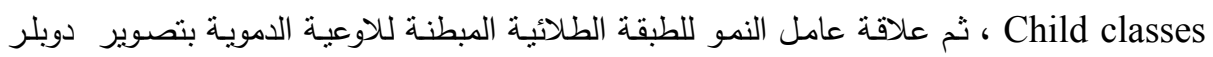
الملون للوريد البابى والوريد الطحالى. وقد اجرى هذا البحث على 00 مريضا بعانون من مرض تليف الكبد مع مقارنتهم بمجموعة

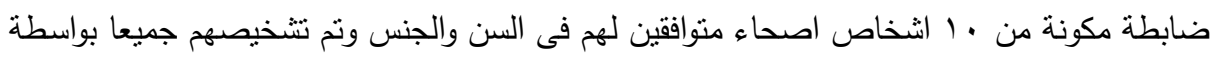

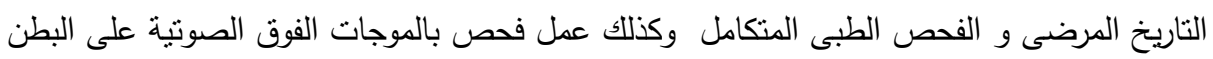
و دوبلر الملون للوريد البابى وقياس ضغط الدم للوريد البابى. ونم قياس مسنوى عامل النمو المبطن للاوعية الدموية وعامل النمو الثبيه للانسولين - 1 بطريقة اليزا.

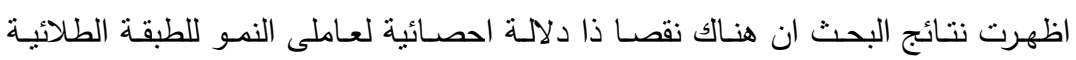

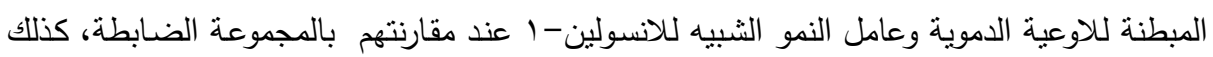

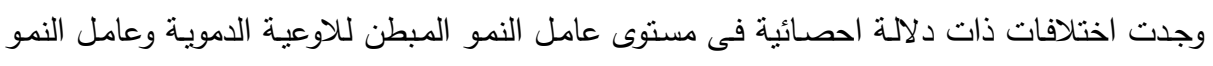
الثبيه للانسولين-1 فى مرضى تليف الكبد حسب تقسيمة Child-Pugh، ووجد ان هناك علاقة

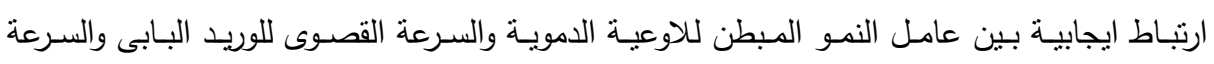

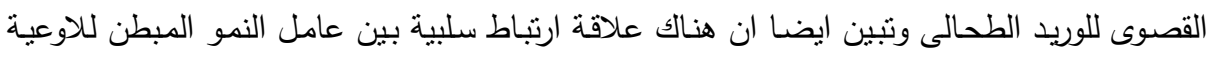

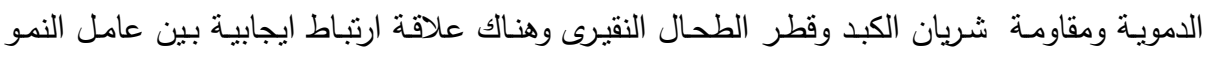
الثبية بالانسولين-1 ومستوى الالبومين ولاتوجد هذه العلاقة مع عامل النمو المبطن للاوعية الدموية. 
ومن ذلك نستتج ان مستوى عامل النمو المبطن للاوعية الدموية فى مرضى نليف الكبد لا

يسنطيع ان يكون مؤشرا لمدى تقدم حالة تليف الكبد، ولكنه ربما يعكس حدوث مضاعفات فى صورة

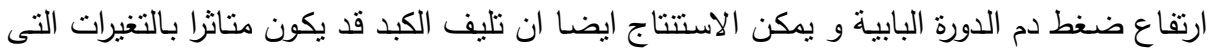

تتطرا لعامل النمو الثبيه للانسولين - التى لها علاقة بدرجة الخلل الوظيفى للكبد. 